Abstracta Iranica Abstracta Iranica

Revue bibliographique pour le domaine irano-aryen

Volume 40-41 | 2019

Comptes rendus des publications de 2017-2018

\title{
Kishwar Rizvi (ed.). Affect, Emotion, and Subjectivity in Early Modern Muslim Empires. New Studies in Ottoman, Safavid, and Mughal Art and Culture
}

\section{Rédaction}

\section{OpenEdition}

1 Journals

Édition électronique

URL : http://journals.openedition.org/abstractairanica/50726

DOI : $10.4000 /$ abstractairanica. 50726

ISBN : 1961-960X

ISSN : 1961-960X

Éditeur :

CNRS (UMR 7528 Mondes iraniens et indiens), Éditions de l'IFRI

\section{Référence électronique}

Rédaction, «Kishwar Rizvi (ed.). Affect, Emotion, and Subjectivity in Early Modern Muslim Empires. New

Studies in Ottoman, Safavid, and Mughal Art and Culture », Abstracta Iranica [En ligne], Volume 40-41 |

2019, document 4, mis en ligne le 30 décembre 2019, consulté le 27 avril 2021. URL : http://

journals.openedition.org/abstractairanica/50726 ; DOI : https://doi.org/10.4000/abstractairanica. 50726

Ce document a été généré automatiquement le 27 avril 2021.

Tous droits réservés 


\title{
Kishwar Rizvi (ed.). Affect, Emotion, and Subjectivity in Early Modern Muslim Empires. New Studies in Ottoman, Safavid, and Mughal Art and Culture
}

\author{
Rédaction
}

\section{RÉFÉRENCE}

Kishwar Rizvi (ed.). Affect, Emotion, and Subjectivity in Early Modern Muslim Empires. New Studies in Ottoman, Safavid, and Mughal Art and Culture. Leiden: Brill, 2017, (Arts and Archaeology of the Islamic World, vol. 9), 222 p., ill., index., ISBN: 978-90-04-34047-3

1 Kishwar Rizvi, professeure d'art et architecture islamiques à Yale University, propose d'aborder le thème des émotions et de la subjectivité à travers une histoire connectée des arts safavides, ottomans et moghols. Les articles des huit auteurs réunis dans ce volume questionnent tant le statut de l'artiste, la représentation qu'il donne de lui (signature, portrait, etc.), que les motivations de la créativité ou encore le rapport au monde de l'individu et ses sentiments, et ce dans différents domaines artistiques (arts du livre, architecture, urbanisme, littérature, etc.).

2 Articles réunis dans ce volume :

3 - Sussan Babaie, " Chassing after the Muhandis: Visual Articulations of the Architect and Architectural Historiography », p. 21-44, (Article recensé dans ce volume)

4 - Marianna Shreve Simpson, «Who's Hiding Here? Artists and Their Signatures in Timurid and Safavid Manuscripts », p. 45-65,

5 - Emine Fetvac1, « Ottoman Author Portraits in the Early-modern Period », p. 66-94, 
6 - Christiane Gruber, «In Defense and Devotion: Affective Practices in Early Modern Turco-Persian Manuscript Paintings », p. 95-123, (Article recensé dans ce volume)

7 - Sylvia Houghteling, "Sentiment in Silks: Safavid Figural Textiles in Mughal Courtly Culture ", p. 124-147, (Article recensé dans ce volume)

8 - Chanchal Dadlani, « The City Built, the City Rendered: Locating Urban Subjectivity in Eighteenth-Century Mughal Delhi », p. 148-167,

9 - Sunil Sharma, "Fā'iz Dihlavì's Female-Centered Poems and the Representation of Public Life in Late Mughal Society », p. 168-184,

10 - Jamal J. Elias, «Mevlevi Sufis and the Representation of Emotion in the Arts of the Ottoman World », p. 185-209.

\section{AUTEURS}

RÉDACTION

Direction et secrétariat d'Abstracta Iranica 